\title{
Alain Legros, Montaigne face à ses censeurs romains de 1581 (mise à jour)
}

Filippo Fassina

\section{(2) OpenEdition}

\section{Journals}

\section{Edizione digitale}

URL: http://journals.openedition.org/studifrancesi/5591

DOI: 10.4000/studifrancesi.5591

ISSN: 2421-5856

\section{Editore}

Rosenberg \& Sellier

\section{Edizione cartacea}

Data di pubblicazione: 1 septembre 2011

Paginazione: 399

ISSN: 0039-2944

\section{Notizia bibliografica digitale}

Filippo Fassina, «Alain Legros, Montaigne face à ses censeurs romains de 1581 (mise à jour)», Studi

Francesi [Online], 164 (LV | II) | 2011, online dal 30 novembre 2015, consultato il 09 janvier 2021. URL: http://journals.openedition.org/studifrancesi/5591 ; DOl: https://doi.org/10.4000/studifrancesi.5591

Questo documento è stato generato automaticamente il 9 janvier 2021.

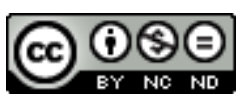

Studi Francesi è distribuita con Licenza Creative Commons Attribuzione - Non commerciale - Non opere derivate 4.0 Internazionale. 


\title{
Alain Legros, Montaigne face à ses censeurs romains de 1581 (mise à jour)
}

\author{
Filippo Fassina
}

\section{NOTIZIA}

ALAIN LEGROS, Montaigne face à ses censeurs romains de 1581 (mise à jour), «Bibliothèque d'Humanisme et Renaissance», LXXI, 1 (2009), pp. 7-33.

1 Il presente contributo analizza dettagliatamente un testo di grande importanza per la comprensione e l'interpretazione dell'opera di Montaigne: si tratta di una lista di animadversions che nel 1581 due censori romani scrissero riguardo agli Essais e che, di fatto, rappresenta un vero e proprio intervento di censura. Tuttavia, tali critiche furono ritirate subito dopo e trasformate in una semplice raccomandazione verbale all'autore, nel caso in cui questi intendesse ripubblicare l'opera. Dopo aver riassunto brevemente le tappe della questione, l'A. elenca in trascrizione i passi degli Essais colpiti dalla censura, con il relativo commento da parte dei censeurs. L'importanza di questo testo è dovuta principalmente al fatto che fino ad ora la critica si è occupata solo a livello superficiale della censura a Montaigne e non ha potuto approfondire le conseguenze di questa sulle varianti presenti nell'edizione del 1582. 